\title{
The use of a website as an interaction and training device in health, gender and work in schools
}

\author{
Jussara Brito $^{\mathrm{a},{ }^{*}}$, Mary Yale Neves ${ }^{\mathrm{b}}$, Amanda Ornela Hyppolito ${ }^{\mathrm{c}}$, Denise Alvarez ${ }^{\mathrm{d}}$, Edil Ferreira da \\ $\mathrm{Silva}^{\mathrm{e}}$, Hélder Muniz ${ }^{\mathrm{f}}, \mathrm{Ká}_{\text {tia Reis de Souza }}{ }^{\mathrm{g}}$, Maristela França ${ }^{\mathrm{h}}$ and Milton Athayde ${ }^{\mathrm{i}}$ \\ ${ }^{a}$ Centro de Estudos da Saúde do Trabalhador e Ecologia Humana, Escola Nacional de Saúde Pública, Fundação \\ Oswaldo Cruz, Rua Leopoldo Bulhões 1480, Manguinhos ,21240-210, Rio de Janeiro, RJ, Brasil. ${ }^{\text {b Departamento }}$ \\ de Psicologia, Universidade Federal Fluminense, Campus do Gragoatá, Rua Prof. Marcos Waldemar de Freitas \\ Reis s/n, bloco O, Sala 218, Gragoatá, 24210-350, Niterói, RJ, Brasil .' Departamento de Saúde e Sociedade, \\ Instituto de Saúde da Comunidade, Universidade Federal Fluminense, Rua Marquês de Paraná, 303, $3^{\circ}$ andar, \\ prédio anexo, Centro, Niterói, RJ, Brasil. ${ }^{\mathrm{d}}$ Departamento de Engenharia de Produção, Universidade Federal \\ Fluminense, Campus da Praia Vermelha, Av. Passos da Pátria 156, bloco D, sala 306, São Domingos, 24201- \\ 240, Niterói, RJ, Brasil. ${ }^{\text {e }}$ Setor de Estudos e Assessoria a Movimentos Populares da Universidade Federal da \\ Paraiba e Departamento de Psicologia da Universidade Estadual da Paraíba,Rua Baraúnas, 351, Bairro \\ Universitário, 58429-500, Campina Grande, PB, Brasil. ${ }^{\mathrm{f}}$ Departamento de Psicologia, Universidade Federal \\ Fluminense, Campus do Gragoatá, Rua Prof. Marcos Waldemar de Freitas Reis s/n, bloco O, Sala 218, \\ Gragoatá, 24210-350, Niterói, RJ, Brasil. ${ }^{g}$ Centro de Estudos da Saúde do Trabalhador e Ecologia Humana, \\ Escola Nacional de Saúde Pública, Fundação Oswaldo Cruz, Rua Leopoldo Bulhões 1480, Manguinhos, 21240- \\ 210, Rio de Janeiro, RJ, Brasil. ${ }^{\mathrm{h}}$ Escola de Letras, Departamento de Processos Técnicos e Documentais, \\ Universidade Federal do Estado do Rio de Janeiro, UNIRIO, Av. Pasteur 458, Urca, 22290-970, Rio de Janeiro, \\ RJ, Brasil. ${ }^{\text {i }}$ Pós-graduação em Psicologia Social, Universidade do Estado do Rio de Janeiro, Rua São Francisco \\ Xavier 524, $10^{\circ}$ Andar, Rio de Janeiro, RJ, Brasil.
}

\begin{abstract}
The objective of this paper is to introduce the Website "Encontros sobre a vida, a saúde e o trabalho nas escolas públicas" (Encounters of life, health and work in public schools). It was designed viewing to contribute to the generation of changes regarding the meanings attributed to work done by all professionals acting in Brazilian public schools, in their relationship to health. We have tried to create a space conducive to reflection and invention of different ways of action towards the struggle for health of the protagonists of the school units. We present the Website's different ambients, such as the one for availability of Training materials, Discussion Forums and the Observatory of facts and events related to the topic. We point out the analysis of a dialogue between the Formaction Program in Health, Gender and Work at Schools. Through the displaying of dialogs that mobilized the training participants we observed a process of collective analysis of the situations that occur at meetings, allowing other interpretation possibilities by the different parties. In the case focused, a nursery assistant (male), in the dialogue, is forced to review his description of the activity, initially, portrayed as simple.
\end{abstract}

Keywords: Public school, occupational health, gender, work activity, training.

${ }^{*}$ Corresponding author. E-mail: jussara@ensp.fiocruz.br 


\section{Introduction}

Since the year 2000 we have been developing a training-research-intervention device on health, gender, and school work relationship network, we called "Formaction in Health, Gender and Public School Work Program" $[12,13]$. The development of this Program - approved and financed initially by the Gender Equality Fund of the Canadian International Development Agency (CIDA) and, later by the Carlos Chagas Research Support Foundation of the Rio de Janeiro State (FAPERJ) and by the Osvaldo Cruz Foundation (FIOCRUZ) allowed the systematization and experimentation of a method in the Rio de Janeiro State and in the City of João Pessoa in the State of Paraíba (Brazil), in a partnership with the State Educational Professional Union (SEPE/RJ) and of the Educational Workers Union of the City of João Pessoa (SINTEM). Thus, a series of potentially health promoting events were and continue being produced from this experiment, having had as starting point a magnified view over singular work situations combined with the experience of the protagonists of the activity.

The method aimed at producing a form of knowledge that was shared among research professionals, trade unionists and the set of school workers (teachers, principals, cooks, janitors, security guards etc.) concerned - considering the gender dimension - with a view to positively transform work. We assumed that the scientific knowledge heritage produced on the subject in focus should be socialized and placed in discussion systematically so that desired changes would occur in a fruitful way.

Thus, the Program was organized in cycles, aiming at the continual increase in training, with workers being responsible for the consecutive cycles in which they participated. Each cycle is divided in two phases (to be presented later), that were planned to allow that the experience - concrete, singular, from each worker, from each collective, from each school - be shared with all. In order to develop this experience [26], the proposed training method emphasizes the synergistic dialogue, discussion, increasing the capacity of work collectives to understand $\leftrightarrow$ transform their work situations.

In this process, the so called "Extended Research Community" (ERC) is engendered - a space of confrontation-cooperation between scientific and practical knowledge $[5,11,12]$ - in conformity to the ergologic perspective $[28,29]$. We have observed that this type of training contributes to the emergence of a diversity of views and conceptions from the workers towards affirmative life actions and of problems of the school work world, the health and gender issues, allowing its denaturalization [4, 18]. Consequently, the development of this program provided changes of various kinds, from those that relate to new processes of subjectivising, through concrete changes in the organization and work environment, to changes in the forms of the struggle for health, with effects on the public policies, or, union structure, for example with the construction of Departments of Health and Gender.

Despite these achievements, we believe that our current challenges are to contribute to the continuity of changes generated in this process and of insights of workers who participated in the training, aiming to strengthen the ERC, as well as to provide a greater dissemination of knowledge on these issues. In other words, we believe that a systematic action aimed at changing the social meanings attributed to educational work carried out in Brazilian public schools is needed, as well as a more comprehensive, qualified and continuous discussion about the health of the protagonists of these activities. It is part of our strategy, therefore, the construction and maintenance of permanent "Observatories" about life, health and work at schools and the expansion of "meetings about work" in the ERCs.

Considering Internet's socializing and developmental potential, we believe that it should be used as a resource for the action mentioned above. In other words, this conglomerate of networks and their services can be used as an opportunity to facilitate and enhance their meetings and communications, overcoming barriers such as geographic distances in a huge country like Brazil, besides disseminating knowledge produced academically and produced from practical work experiences at schools.

The Website "Meetings on life, health and work in public schools" envisages stimulating debate about these themes, contributing to the generation of virtual meetings of all of those who are interested in this theme, especially educational workers, researchers and healthcare professionals. We have tried, as said before, to create a space conducive to reflection and invention of different ways of action towards the struggle for health of the protagonists of the school units.

The aim is to contribute to a renewal of the senses that are assigned to the work of all employees who are mobilized so that the school has vitality and 
reaches its goals, despite the immense structural problems that breed harmfully in everyday life. It is also intended that this Website streamline the connections of a national and virtual network for training, news, analyses and reflections of different aspects of the health of educational workers, and the perspective of expansion of the ERC.

This paper aims, therefore, to present the Website's configuration, giving special emphasis the analysis of dialogues produced during the Formaction Program in Health, Gender and Work at Schools. Language materials of this kind will be disseminated in one of the Website's ambients (which will be shown later in this paper), aiming at feeding the dialogical chain [16] relative to the issue.

\section{Theoretical-methodological aspects}

\subsection{Assumptions}

- The production of knowledge about work demands confrontation of different knowledge, through an agreed dialogue, triggering a threepole dynamic device - as proposed by Ergology [28]. It is considered that the process of comprehension $\leftrightarrow$ transformation of work situations must come from the dynamics of confrontation between scientific and practical knowledge. Thus, the configuration of the Website believes that this exchange should be privileged in the way it will be nurtured over time. On the other hand, the "activity point of view" [6 - 8], central in this type of tool, should articulate different scientific fields pertinent to work, school education and health, to the extent that we agree to Schwartz [28] that activity permeates conscious and unconscious, verbal and non-verbal, biological and cultural, highlighting the transversality of gender relations.

- Health as a normative, production of new life norms. Based on Canguilhem [9], Schwartz [28] and Dejours [1], health is seen not as something ecstatic and opposed to illness, but as permanent dynamic struggle. For Canguilhem [9], this is linked both to the environment in which we live, and to the ability we have and develop, individually and collectively, to transform it according to our wishes. It is a notion associated to the capacity of production of new life norms (not only the mere absence of illness) and which highlights the existence of a dimension of the human body only accessible to individual himself, signaling the necessity of constant dialogue with the one who lives the experience of his own body, pain, illness to understand it $[12,13,15]$.

- Dialogism as a constitutive principle of language. For the theory of the dialogic relations [16], dialogism and verbal interaction are key concepts. If considered alone, the utterance is individual, but its existence is always part of a verbal interaction chain. Even a text written in a personal diary answers to a situation and has an addressee, so it is suitable to understand it and approach it in its dialogic nature. The verbal interaction, therefore, is not restricted to what happens face-to-face between two individuals, in a dialogue produced by concatenation of utterances. Its observation calls for a broader perspective from a dialogic view [17] in which the interaction is understood as a broad concept in the sense of an interaction placed in and by the set of multiple discourses of a given society at a given time.

- Training in a network and from generator themes as means of action. We agree with [23], that collective working tools can be produced engendering a collective intelligence - that are coherent with the new ways of collaborating to the production of knowledge where the construction of a socio-technical network is both the instrument and means of developing the capacity of action of workers and researchers. The virtual networks may be strategic tools for the continuous training, renovating the dialogue spheres and of interactivity between workers in order to negotiate and promote changes in work, with the workplace as main reference, since they are privileged spaces of reflection-action over the concrete, its obstacles, conflicts and possibilities. The "generator themes" [21] according to the tradition of popular education in Brazil, are considered strategic tools to guide the continuous training network. Training becomes a means of ergonomic transformation action, since it derives from a change of point of view, of a perceptual and conceptual opening. Thus, the consistency of change is found both in the fertility of the analyses performed, and in the comprehension and trust of pertinent project workers and managers [3]. 


\section{- 2.2 Procedures}

Based on the assumptions signaled above, the Website's conception as a tool and defining how it will be fed implied in the following procedures:

- Creation of a Website interdisciplinary coordination group and of different work groups responsible for specific parts, seeking to provide various readings of the question, from the activity point of view.

- Analysis of the material produced along the Formaction in Health, Gender and Public School Work Program: reports, dialogue transcriptions, film and photographic registers.

- Website ambient definitions, considering the compiled and analyzed material, envisaging:

* different forms of interaction with workers and their unions;

* the constant updating of the scientific production on the theme;

* general monitoring of the debate on the theme in the country.

- Definition of the Website's architecture and the language adopted in naming the ambients and their contents, in consonance to their purposes and assumptions, especially regarding the establishment of a fertile communication with users, particularly school workers.

\section{Results}

First, we introduce the set of environments that are part of the Website configuration "Meetings on life, health and work at public schools". After, amongst the various dialogues which occurred during the experimentation of the Formaction in Health, Gender and School Work, we explored briefly the discussion-confrontation which occurred in one of the ERC meetings on the specific nursery assistant's activity tasks.

\subsection{Website configuration}

$1^{\text {st }}$ Ambient - the ERC school: This ambient leads to the production team responsible for coordinating and administering the Website, as well as readings and authors considered essential to address the relationships between life, health and work in public schools.

$2^{\text {nd }}$ Ambient - Formaction in Health, Gender and Work at Public Schools Program: To better understand this Website ambient, it is essential to describe the two phases that comprise the method adopted in each cycle of the Formaction Program:

Phase 1 - course, initially scheduled for 20 hours, to which it is previewed linking to the following moments:

- exposure of the "generator themes" [21], aiming to inform participants about what is considered more relevant in the scientific field;

- reading of texts, in small groups (or individually), on the generator themes presented, using the Textbooks produced by the team for this purpose;

- discussion in these small groups [24], on the topics addressed, with a coordinator and one or more observers. Inspired in "Pedagogy of the Asking" [22] a dialogic movement is produced, effecting in greater involvement, compromise [21] and development of the participants (individual and collective). In this group work, the coordination's role is not to validate this or that understanding, but strictly contribute to the questioning of the subject, as well as formulations initially presented by the exhibitor and the text.

- socialization of the matters discussed in the small groups, followed by a new debate with the entire group, not looking for a summary, but considering these discussions as an open work, in its indetermination [25].

To end this phase, the three last course sessions are reserved for programming the continuity of the Formaction Program - which implies the definition of focus for the field study exercises ( $2^{\text {nd }}$ phase $)$. The proposal of study focus is based in the analyses of group and subgroup discussions.

Phase 2 - switches between field studies and ERC meetings:

$-1^{\text {st }}$ moment: after the course, workers return to the schools to practice the field studies focused;

$-2^{\text {nd }}$ moment: systematic ERC meetings, after each exercise, to discuss the experience, the findings and the possible changes to be experimented and eventually claimed for the entire school system.

Thus, a set of materials produced within the Program is disseminated by the Website. The first relates to the methodological orientation; Method and Procedures Booklet. The second concerns several texts proposed for discussion within the ERCs to be constituted, the Textbook. The third gathers materials produced by workers who participated in the first Formaction Program cycle: 
The Experience Report Booklet. We also provided the video that presents this experience systematically: "Work in Schools? Only by inventing pleasure".

In this ambience the school workers that visit the Website are also invited to express themselves on certain issues, or, in Paulo Freire's conception [20] "generator themes", expecting they will produce forms of action aimed at life and health affirmatives in the workplace.

A space for the display and analysis of dialogues that took place at different moments of the development of the Formaction Programme (discussion groups, ERC meetings) is provided, in order to assist in understanding the issues involved in the work in schools, gender and health relationships and to feed the dialogic chain of matters treated in different moments. In item 3.2 we will present the analysis of a dialogue excerpt from one of the Programme meetings, considering that the example given will allow a better visualization of how these materials will feed the Website continuously.

$3^{\text {rd }}$ Ambient - General Observatory: The General Observatory aims to follow the facts, events and discussions on the website's theme; union initiatives; governmental policies and actions; events; academic activities; articles and texts published in newspapers and magazines; situation analyses; besides communications sent by workers and reports from the members of the team responsible for the administration.

$4^{\text {th }}$ Ambient - ERC member's network: The ERC network is a private ambient reserved for school workers who already participate in the Formaction Program. It is a space directed to the continuation of exchanges between the different knowledge and the multiplication of experiences, departing from discussion forums of strategic themes. The idea is to create favorable conditions to a permanent dynamic synergistic dialog, providing common areas in terms of depth of knowledge and positive changes in life [29].

When adopting strategic themes to stimulate the discussion, we aim at organizing dialogue, as said above, under the conception of generator themes, as traditional of popular education. The intention is to challenge the users to express their opinion, in a live, personal and "public" way. The main reason for adopting the generator themes, as part of training, is the interest in arousing the discussion of ideas in a circumscriptive way [22].
This way, the ERC Members Network is organized in five discussion forums, involving themes evaluated as strategic, as can be seen bellow:

- Actions and everyday inventions to promote health;

- Looking at the school space and its surroundings;

- Signs of malaise... and how to deal with them;

- Pleasure and pain of working in a public school;

- Other themes?

Dividing by themes was a didactic recourse: in reality, the generator themes are always interwoven. While dealing with a theme others arise; when pulling a thread, one discovers a complex network, a network of questions that are interconnected to life, work and health. Moreover, it is intended to guide the dialogue, promoting challenges on where the critical thinking should focus, at the same time as it allows openings towards other themes. Finally, what we want to achieve are the workers' very thoughts on the relationship between work and health at schools, on formulating their vision of world and written word at the forums.

Freire [19] emphasizes the dynamic movements that occur in the relationship between word and world and states that written text may incite a means of operating knowledge actively. As for the act of reading, it can stimulate the knowledge of the world and, additionally incentivizing workers to write about their own reality. At the discussion forums, through the written word, people get prepared to intervene and to position themselves [20]

The discussion about reality at work - as 'the real of work [1], the 'real of activity [27] - and health, from predefined themes, allows a continuous analysis of these issues by several subjects. We intend, therefore, to give visibility to the subject in the same (virtual) space, but originated from different schools, an analyzing their conditions and relationships woven into the daily work.

$5^{\text {th }}$ Ambient - Contributions: The objective of this ambient is to present different scientific contributions regarding the subject dealt with, gathering papers, thesis, dissertations, monographies, reports and other texts elaborated by researchers and students linked to the team responsible for the Website. There is also space to disseminate contributions from other colleagues and research groups we consider relevant.

$6^{\text {th }}$ Ambient - Galleries: This ambient will allow visitors to visualize photographs that register various moments of training since the year 2000, as of 
diagrams and slides produced during the whole Program.

\subsection{Dialogue between task and nursery assistant activities}

As said above, an area of the Website is reserved for the exhibition of texts registered within the framework of a dialogical process in which they were developed.

The ethical-aesthetic objective of bringing spoken events is to contribute to feed the dialogic ERC chain.

Understanding with Bakhtin [16], the dialogical character as constitutive of the whole idea of language, the ERC meetings propose confront the worker to his work in its relationship with reality and, thus, with their own work and those of others. The different points of view the polyphony orchestrated in the confrontation that produces new texts, from the necessity of redrawing descriptions, even if very timidly (as in the situation described bellow, for example), places in the dialogic horizon a rethinking of the work activities, thus constituting the theme to a new addressee.

The choice of texts to be presented in the site aims to expose some dialogue situations - chosen amongst those that especially mobilized the participants along the language exchanges. This choice relates to how the occurrence of certain "appreciative verbal gestures" draws the attention of research professionals. These gestures refer to:

- voice: variations in volume, rhythm, intonation;

- the word order: the manner in which words are placed side by side in the uttering;

- the words themselves: certain lexical choices made;

- the cited speech: specifically the occurrence of direct speech, of rhetoric direct speech and of free indirect speech [17];

- to crosstalk: departing from the history of occurrence of certain utterances in previous meetings, in the media, and in other means.

Thus, the chosen excerpts involve moments where the sense/reasons of working at school are discussed and transformed, showing the controversies and the openings for new ways of conceiving and doing activities. In these excerpts there are discussions between school workers and research professionals and between workers. The discursive exchange presents a collective analysis which happens at meetings. Besides, the reading by various parties
(Website users) allows other interpretation and analysis possibilities of dialogues generated in a determined ERC meeting.

We registered that the type of analysis we present bellow, as an example, is displayed on the Website in a manner appropriate to a better understanding by the users. The dialogue excerpt occurred in an ERC meeting in which, from a question asked by researchers on the characteristics of nursery assistants' work, two of them (one male and one female) started to discuss their activities. The controversy that arose was the potential source to change and expand gradually the sense this activity had for workers and researchers, from the question asked by the researcher 1: "What kind of work is this?". Follows the dialogue excerpt:

1 Nursery assistant 1: Theoretically it is more administrative. It is not a pedagogic work nor did anything relate to it. The nursery assistant's functions is what? Taking care the child is clean, bathe it, clean its bottom, change diapers, that's it!

2 Nursery assistant 2: Play with them.

3 Nursery assistant 3: Legally speaking he would have to do this. That's his function, only he doesn't do it. He does more. So, whoever enters a room as dirty as he does, theoretically he will do a work in a very... Because he won't enter the room on his own, he'll have people there with him to help. And these people can help him with the easy work. "pay attention to the child, etc!" Theoretically he can do this. He has the power to enter the room and do the work.

4 Researcher 2: The question you made, I think it was L. who brought another question, she spoke, didn't she? A child who bites, a child who hits and which we have to know how to deal with, to... so, then I want to re-dimension this you brought up which seems it not as simple as that, it is not administrative. You yourself are giving another dimension there.

5 Researcher 3: I would like to speak too.

6 Nursery assistant 3: I am already taquicardic (laughs). No, it shocks me, he saying it's a simple job 'cause for me it isn't.

7 Nursery assistant 2: No, it's not!

8 Nursery assistant 3: It's not, you know..

9 Nursery assistant 2: Sick children...

10 Nursery assistant 3: I've been working for some time and I think W. (NA1) is referring only to what is in the edictal, to what the post...

11 Researcher 3: ...to the prescribed.

12 Nursery Assistant 3: ... but not to the real situation. Why don't I understand? "very simple". Because it's not only the care taking. The bath giving. That bath giving also has a pedagogic effect. Feeding also has a pedagogic effect. And so, all the time we worry about directing each activity we are performing at the nursery to an objective. We have an objective. Even when you're giving a bath, you're feeding, which seems to some people to be something simple. For example, let's say, that a general services assistant doesn't have the capacity to do this in my nursery. There was one, who was a general services assistant who now is a very capable recreator. But this is how I perceive it... it's...like someone who doesn't know child development, for example, doesn't have the perception - somebody here commented: "the 
child is eating because there was a change of teachers". So, what will be the action of this person who doesn't have this differentiated look? If they think it's only a body that is being taken care of? And where is the head located? And the mind? We have to work the whole, the whole human being. So then, it gives me tachycardia whenever I hear him say that it's simple. It isn't. (various voices)

13 Nursery assistant 1: When I say it's simple, if I remove all the questions involved about... it's simple in the sense that there are limiters, do you understand? Of course there are these particularities of a complex job. I also think I made a mistake when I said it was simple. (various voices)

14 Nursery assistant 3: Not even the administrative tasks were simple. (various voices)

We see that NA1's (male) language/action suffers the impact of various individuals in the dialogue (mostly female), but especially from the language/action of NA3 (line 6) to whom this uttering offers a distorted image of what for her was the nursery assistant's job, leading her to a counterword. In it, NA3 shows she identifies NA1's intentions towards the action of demanding and justifying the presence and help of another professional of the team, who's absent: a cleaning assistant ("For example, lets say that a general cleaning assistant is not ignorant [...]" - line 12), but does not abandon, on her turn, the project of sharing her own experience and emotion "So then, it gives me tachycardia whenever I hear him say that it's simple." (end of line 12). NA1 is forced to review the description made, that it is maybe contaminated by the professional devaluation present in the male experience in relation to the health care activities with small children. Of course, the sexual division of work and the "macho" prejudice should be analyzed $[2,10]$. The ERC dialogic situation produces means for new objectives, as reviewing what one said to be able to rephrase: "Of course there are these particularities of a complex job. I also think I made a mistake when I said it was simple".

But the absence of clashing of something fundamental persists, although it remits to an action that extrapolates the power of those parties present at the dialogue: the professional distortion of the assistant nursery's image. Given the impoverishment process of the school network, the task itself is distorted by the absence of another primordial professional, the "service assistant": "Because he won't enter the room alone, he'll have people there with him to help".

The NA who answers initially to the Researcher 1 's poses the problem, although not in a direct way, nor positioning the words in their proper place. When appointing what was said in line 13 as "limiting", he initially verbalizes using the following expression: "in a more administrative way" (not expliciting clearly that they are tasks that would be a function of the "support professionals", as the so called "general service assistants).

Remember that this is a very difficult change, as it is a governmental responsibility, up to now systematically blind to the problem and deaf to the permanent reinvidications of the trade unions.

In this context, one can understand that the main addressee of NA1's speech is the state apparatus in the field of Education. He speaks unclearly of what the trade unions have already found out in the history of their struggles. And, solitarily, tackles this powerful collocutor in a very inaccurate way. He appoints another absolutely fundamental dimension that is the composition of the nursery working team, a collective that should be respected and defended of the violences of eventual governors in power.

How to stage the set of actors that circulate in nursery work is indeed a major challenge. How to put in synergy classic questions of the union movement, as the struggle against exploitation, adding factors that are not part of the tradition, as the sexual division of labor? It is a task of great importance and complexity, to which a devise such as the Website proposed, may play an important role, although we do not know to what extent, only experimenting it.

This view considers that men and women not only become known by the texts, but also they are constructed by/with them. In the dialogue fabric, the word of others plays a key role in order that a personal encounter with the word happen, one's own word, in its' inevitability of being from no other - the result of an individual experience of life and work.

Thus, when exposing excerpts of dialogues such as this one in the Website, accompanied by an attempt of analysis, we believe that other voices will join in the discussion initiated in a specific context of the Formaction Program. In the example above, the discussion between task and the activity of nursery assistants will be shared by many, as well as the questioning on the necessary composition of the team.

\section{Final considerations}

The Website brings the possibility - as [23] defends - of leveraging a network of interfaces that will allow to subtract from experts the absolute 
domain of analysis and invite those interested in the work and life in schools to share a process of knowledge production. Thus, the Website becomes a resource for the various school workers to analyze their own work and its relation to health.

We emphasize that all the Website's ambients should contribute to the training of these workers, be it by providing rewarding material and furnishing bibliographic references of texts deriving from researches, be it propitiating the dialogue between them, be it even disseminating facts and rethought on the matter.

It is a training tool whose expected outcome is the transformation of senses of work in the Brazilian public school network, contributing this way to the concrete transformation of the various activities that are conducted within these institutions, having as final destination the affirmation of life and the achievement of health.

\section{References}

[1] C. Dejours. Travail vivant 1: sexualité et travail. Paris: Payot, 2009.

[2] D. Kergoat. A relação social de sexo: a reprodução das relações sociais à sua subversão. Pro-posições, 13(1): 47-59, 2002

[3] C. Teiger; M. Lacomblez. L'ergonomie et la trans-formation Du ravail et/ou des personnes (2). Education Permanente, 166, 9-28. 2006.

[4] E. F. da Silva. Trabalhadores/as de escola e construção de uma "Comunidade Ampliada de Pesquisa": a busca da promoção da saúde a partir dos locais de trabalho. Tese (Doutorado) Escola Nacional de Saúde Pública, Fundação Oswaldo Cruz, Rio de Janeiro. 2003

[5] E. F. da Silva; J. Brito; M. Y. Neves; M. Athayde. A Promoção da Saúde a partir das Situações de Trabalho: Considerações referenciadas em uma experimentação com trabalhadores de escolas públicas. Interface - Comunicação, Saúde, Educação. Botucatu. 2009.

[6] F. Daniellou. Introdução: Questões epistemológicas acerca da ergonomia. In:Daniellou, F. (Org.). A ergonomia em busca de seus princípios. São Paulo: Edgard Blücher, p. 1-13. 2004.

[7] F. Daniellou; A. Laville; C. Teiger. Ficção e Realidade no Trabalho Operário. Revista Brasileira de Saúde Ocupacional. São Paulo, v. 17, n. 68, p. 7-13. 1989.

[8] F. Guérin; A. Laville; F Daniellou; J. Duraffourg; A. Kerguelen. Compreender o trabalho para transformá-lo: A prática da ergonomia. São Paulo: Edgard Blucher. 2001

[9] G. Canguilhem, O normal e o patológico. Rio de Janeiro, Forense, 2006, 6a. ed.

[10] H. Hirata. Nova Divisão Sexual do Trabalho? Um olhar voltado para a empresa e a sociedade. São Paulo: Boitempo, 2002.

[11] J. Brito; M. Athayde. Trabalho, educação e saúde: o ponto de vista enigmático da atividade. Trabalho, Educação e Saúde, v.1, n.2, p. 63-89, 2003

[12] J. Brito; M.Athayde, M. Y. Neves (Orgs). Caderno de método e procedimentos. Programa de Formação em Saúde, Gênero e
Trabalho nas Escolas. João Pessoa: Ed. Universitária UFPB, 2003.

[13] J. Brito; M. Athayde, M. Y. Neves (Orgs) Caderno de textos. Programa de Formação em Saúde, Gênero e Trabalho nas Escolas. João Pessoa: Ed. Universitária UFPB, 2003.

[14] J. D. Costa. O "Programa de Formação em Saúde, Gênero e Trabalho em Escolas Públicas" e a produção de subjetividades. Dissertação (Mestrado). Programa de Pósgraduação em Psicologia Social, Universidade Federal da Paraíba, João Pessoa. 2004.

[15] M. Athayde; H. Muniz; M. França; M. G. Figueiredo. Perspectiva da Ergologia e o Campo da Saúde Mental e Trabalho. In: Débora M. R. Glina; Lys Esther Rocha. (Org.). Saúde Mental e Trabalho. $1^{a}$ ed. São Paulo: Roca, p. 229-247. 2010

[16] M. Bakhtin. (1976) Estética da criação verbal. 5ª ed. São Paulo: Martins Fontes, 2010.

[17] M. Bakhtin (V.N. Volochínov). (1929a) Marxismo e Filosofia da Linguagem. 13 ${ }^{\mathrm{a}}$. ed. São Paulo: Hucitec, 2009.

[18] M. Neves; H. Muniz; E. Silva; J. Brito; M. Athayde; J. Costa. Comunidade Ampliada de Pesquisa: pesquisadores e trabalhadores/as de escolas públicas colocam seus saberes em sinergia na busca da promoção da saúde a partir dos locais de trabalho. In: Krutzen, E. C. \& Vieira, S. B. (Orgs.). Psicologia social, clínica e saúde mental. João Pessoa: Editora UFPB. pp 448-474, 2007.

[19] P. Freire. A importância do ato de ler. São Paulo: Editora Cortez; 1982

[20] P. Freire. Educar: ler, escrever e contar mais, ouvir, falar e gritar. In: Gadotti M, Freire P, Guimarães, S. Pedagogia: diálogo e conflito. São Paulo: Editora Cortez; p. 109-124. 1995.

[21] P. Freire. Pedagogia do oprimido. 10a ed. Rio de Janeiro: Editora Paz e Terra; 1988.

[22] P. Freire; A. Faúndez. Por uma pedagogia da pergunta. Editora Paz e Terra. Rio de Janeiro. 1986.

[23] P. Levy. A inteligência coletiva: por uma antropologia do ciberespaço. São Paulo: Loyola, 2000.

[24] R. B. Barros. A afirmação de um simulacro. Porto Alegre: Salina/UFRGS Ed., 2007.

[25] U. Eco. Obra aberta. São Paulo: Perspectiva, 2001, $8^{\mathrm{a}}$ ed.

[26] Y. Clo. Travail et pouvoir d'agir. Paris : PUF, 2008

[27] Y. Clot. A função psicológica do trabalho. Petrópolis: Vozes, 2006

[28] Y. Schwartz. Le paradigme ergologique ou um métier de Philosophe. Toulouse: Octarès, 2000.

[29] Y. Schwartz. O homem, o mercado e a cidade. In: Y. Schwartz \& L. Durrive (org.), Trabalho \& Ergologia: conversas sobre a atividade humana. Niterói: EDUFF, 2a. ed. Revista e ampliada. 2010 